Edith Cowan University

Research Online

ECU Publications 2013

$1-1-2013$

\title{
Release of dissolved organic carbon from seagrass wrack and its implications for trophic connectivity
}

\author{
Paul S. Lavery \\ Edith Cowan University \\ Kathryn M. Mcmahon \\ Edith Cowan University \\ Julia Weyers \\ Mary C. Boyce \\ Edith Cowan University
}

Carolyn Elizabeth Oldham

Follow this and additional works at: https://ro.ecu.edu.au/ecuworks2013

Part of the Marine Biology Commons

10.3354/meps10554

This is an Author's Accepted Manuscript of: Lavery, P. S., Mcmahon, K. M., Weyers, J., Boyce, M. C., \& Oldham, C. (2013). Release of dissolved organic carbon from seagrass wrack and its implications for trophic connectivity. Marine Ecology Progress Series, 494(1), 121-133. Available here

This Journal Article is posted at Research Online.

https://ro.ecu.edu.au/ecuworks2013/771 
3 Paul S Lavery ${ }^{1}$, Kathryn McMahon ${ }^{1}$, Julia Weyers ${ }^{2}$, Mary C Boyce ${ }^{1}$ \& Carolyn E Oldham ${ }^{2}$

$5{ }^{1}$ Centre for Marine Ecosystems Research, Edith Cowan University, 270 Joondalup Dve, 6 Joondalup WA 6027, Australia

$7 \quad{ }^{2}$ School of Environmental Systems Engineering, The University of Western Australia, 8 Crawley WA 6009, Australia

9 *Corresponding author: p.lavery@ecu.edu.au

\section{ABSTRACT}

The export of old leaves and stems (wrack) from seagrass meadows provides a mechanism for trophic connectivity among coastal ecosystems. Since little of this wrack is consumed by mesograzers, leached DOC may determine the importance of wrack as a trophic subsidy. However, few studies have examined the effect of seagrass type or age on the release of DOC or its bioavailability. We examined the amount and composition of DOC released from different wrack (Posidonia sinuosa, Amphibolis antarctica and the alga Laurencia sp.). We then examined the effect of age on DOC leaching from P. sinuosa wrack. The bio-availability of the DOC was also assessed using a bacterial bioassay.

The rate of DOC leaching from Posidonia sinuosa leaves decreased exponentially with time. According to that exponential model, about $50 \%$ of the total DOC release occurred in the first 14 days and it would require a further 2.94 years to release the same amount again. Fresh algae (Laurencia sp.) leached the greatest amount of DOC in the first $16 \mathrm{~h}\left(6.7 \mathrm{mg} \mathrm{kg}^{-1} \mathrm{FW}\right.$ wrack), followed by fresh P. sinuosa leaves (1.7 $\left.\mathrm{mg} \mathrm{kg}^{-1} \mathrm{FW}\right)$, A. antarctica leaves (1.1 mg 
$\left.\mathrm{kg}^{-1}\right)$ and stems (0.6 mg kg$\left.{ }^{-1}\right)$, 4 wk old P. sinuosa $\left(67 \mathrm{mg} \mathrm{kg}^{-1}\right)$ and fine detritus $\left(74 \mathrm{mg} \mathrm{kg}^{-1}\right)$. In all cases, the composition of the DOC was similar and dominated by the hydrophilic component (in $P$. sinuosa, predominantly sugars and amino acids). Leachates from all fresh wrack supported bacterial growth over $24 \mathrm{~h}$. Leachate from older wrack either failed to support bacterial growth, or only supported it for a limited time. Given the exponential decay in DOC release rate, the interacting timescales of transport and leaching will affect the value of wrack as a vector for trophic subsidies.

\section{INTRODUCTION}

Seagrass meadows are conspicuous and highly productive components of coastal ecosystems worldwide (Green \& Short 2003). A portion of seagrass production is continually shed as old leaves, which can contribute significantly to wrack (detached macrophyte) accumulations in adjacent coastal habitats (Kirkman \& Kendrick, 1997; Mateo, 2010). Export rates of detached leaves from meadows varies enormously but can be as high as $100 \%$ of leaf production (Cebrian \& Duarte, 2001; Mateo, 2010; Mateo et al. 2006). Given that these older leaves also contain nutrients other than carbon, even after re-sorption prior to shedding (e.g., Prado et al., 2008) this wrack export represents a significant potential loss of nutrients from the habitat and a potential trophic subsidy to adjacent recipient habitats, particularly in oligotrophic environments where alternative sources of nutrient may be limited.

Despite this potential, there is little published evidence of seagrass wrack being an important source of nutrient to adjacent habitats. Several studies concluded that seagrass wrack was unlikely to be a significant contributor to meso-grazer production in recipient habitats, including unvegetated marine habitats (Hyndes \& Lavery 2005), beach ecosystems (Ince et al., 2007), surf zones (Crawley et al., 2009) and within seagrass meadows (Smit et al., 2005; 
Smit et al., 2006). Wrack typically has a large proportion of macro-algae, and many mesograzers demonstrate a preference for this over seagrass detritus (Doropoulos et al., 2009), likely due to the lower C:N ratio of algae. This suggests that if the nutrients within seagrass wrack are to be recycled within meadows or provide a subsidy to adjacent systems, then mechanisms other than direct consumption of seagrass detritus must be important, microbial pathways utilizing dissolved organic carbon (DOC) being among the most likely.

Fluxes of DOC to overlying water are higher in seagrass meadows than adjacent unvegetated meadows (Barrón \& Duarte 2009). Up to 50\% of this DOC is consumed by bacteria (Ziegler \& Benner 1999), which can be rapidly transferred to higher trophic levels through consumption by flagellates and ciliates (Robertson et al., 1982). The seagrass leaves themselves are a major contributor to this DOC flux. Through exudation or autolysis and leaching, seagrass leaves typically release $2-10 \%$ of net primary production (Moriarty \& Pollard 1982, Barrón \& Duarte 2009), and this leaf-derived DOC has been shown to support bacterial production (Brylinsky, 1977; Kaldy et al., 2006).

Because seagrass leaves degrade much more slowly (Klumpp \& Vandervalk 1984, Moore \& Fairweather 2006) than the rate at which they are transported by currents and storm-driven advection, DOC leaching may occur over extended periods of time and encompass a range of different habitats. This may provide a mechanism of cross-habitat trophic subsidy not dependent on the direct consumption of leaves. Thus, the loss of DOC from seagrass leaves is potentially a key contributor to the total DOC flux from seagrass ecosystems and cross-habitat trophic subsidies.

Almost all of the studies that have examined the loss of DOC from seagrass leaves have focused on living or fresh leaves (e.g. Brylinsky, 1977; Robertson et al., 1982; Wetzel \& 
Penhale, 1979). Yet there is evidence that the age of detached leaves has a significant impact on DOC leakage and in the composition (and therefore bioavailability) of that DOC (Maie et al., 2006; Velimirov, 1986), which may be crucial for the transfer of seagrass-derived nutrients to adjacent ecosystems. Furthermore, the amount and rate of DOC leaching, and the ability of microbes to utilise the leachate, varies among different vascular plants (Benner et al., 1986; Maie et al., 2006), suggesting that the export and bioavailability of seagrass-derived DOC may be species-dependent. Among the seagrasses, inter-specific differences could relate to the anatomy of the plants (e.g. membranous, leafy species such as Posidonia spp. versus heavily lignified species such as Amphibolis spp.) or the amounts and forms of soluble compounds within the tissues. These differences among species in DOC leaching and its apparent bioavailability led Maie et al. (2006) to call for more studies into the bioavailability of the DOC fractions that are released from macrophyte leaves. Further, the potential significance of seagrass as a source of DOC to the coastal zone, coupled with the rapid decline in seagrass cover in recent decades (Green \& Short 2003), prompted Barrón \& Duarte (2009) to call for more studies on seagrasses to understand the export of DOC from these systems and its significance.

In this paper, we compare the amount, composition and bioavailability of DOC released from different types of seagrass wrack. We also examined the effect of wrack age on the amount of DOC released and its bioavailability. The main objectives were to: 1) determine the amount and functional composition of DOC released from different wrack materials. We tested the hypotheses that the amount of DOC released will vary among different types of wrack and that functional composition will vary among types of wrack; 2) examine whether the amount and composition of DOC released from Posidonia sinuosa wrack depended on wrack age. We tested the hypothesis that the amount of DOC released would diminish with age of wrack and that the composition would differ among wrack of different ages; and 3) assess the bio- 
availability of DOC released from wrack and whether this is affected by wrack age. We

106 hypothesised that bacterial biomass would increase more rapidly when grown in leachate than blank solution, and more rapidly in leachate from fresh wrack than aged wrack.

MATERIALS \& METHODS

\section{Study region}

112 The study was conducted on wrack accumulations in Geographe Bay (Fig 1), a 100 km wide north-facing embayment, on the south-western coast of Australia. It is a relatively protected

114 bay with extensive beds of seagrass Posidonia sinuosa Cambridge \& Kuo, and Amphibolis

115 antarctica (Labillardiere) Sonder et Ascherson ex Ascherson. Posidonia and Amphibolis are

116 the dominant meadow-forming genera of seagrasses in south-west Australia. Posidonia spp.

117 produce above-ground shoots with 1-3 strap-like leaves that are periodically shed. Amphibolis spp. have heavily lignified and persistent stems on which clusters of short leaves are borne (Ducker et al., 1977). The stems are often heavily covered by epiphytes, particularly red (rhodophyte) macro-algae such as Laurencia sp (Lavery \& Vanderklift 2002).

121 Extensive accumulations of detached seagrass leaves and stems are typical of the region, especially in winter (McMahon et al., 1997). The bay is exposed to the NW-winds that characterise the early phase of storms in the region. This exposure results in the transport of wrack throughout the Bay, providing a high degree of connectivity among seagrass and other habitats in the region. The wrack is typically dominated by $P$. sinuosa, with significant amounts (up to $30 \%$ by weight) of A. antarctica at times and generally a low amount (but occasionally up to 15\%) of red algae (McMahon et al., in review). Geographe Bay is an oligotrophic waterbody and, as such, the decomposition of wrack in sub-tidal and beach habitats may be a vital source of recycled nutrients (Robertson \& Lenanton 1984). 


\section{Release of DOC from different wrack material}

132 The effect of wrack type on the amount and composition of DOC leachate was examined by comparing DOC leached from wrack commonly found in the region: the seagrasses Posidonia sinuosa (leaves) and Amphibolis antarctica (leaves and stems); the red algae Laurencia sp., which is common as both a free-living algae and epiphytic on seagrasses; and the fine

136 particulate organic fraction $(>0.1-<1 \mathrm{~mm})$ of beach-cast wrack that had been on the beach

137 for at least 2 months. Fresh samples of P. sinuosa, A. antarctica and Laurencia sp. were 138 collected from meadows in $0.5 \mathrm{~m}$ depth. Beach-cast wrack was collected from Busselton 139 Beach, Geographe Bay (S 33 39.317’, E $115^{\circ} 16.812^{\prime}$ ) and then sieved to separate the fine 140 fraction. Samples were stored at $4^{\circ} \mathrm{C}$, for no more than 12 hours, until leachate was collected.

The effect of wrack age on DOC leaching was examined using one wrack type, $P$. sinuosa leaves. We focused on P. sinuosa since this was the dominant component of the beach cast wrack, typically accounting for more than $60 \%$ by biomass. Fresh samples of $P$. sinuosa were collected from a meadow in $0.5 \mathrm{~m}$ depth. The fresh material was transported immediately to the laboratory and stored in a cool room at $4^{\circ} \mathrm{C}$ for a maximum of 2 days until leachate was collected. For 'aged' material, approximately $500 \mathrm{~g}$ of fresh $P$. sinuosa was placed in nylon mesh litterbags (mesh size $<5 \mathrm{~mm}$ ) which were then placed on the surface of wrack accumulations on the beach, held in place by pickets driven into the wrack accumulations, and exposed to the ambient weather conditions. Replicate bags $(n=3)$ were removed after 1,2 , and 4 weeks and returned to the laboratory for leachate experiments.

\section{DOC leachate extraction}

154 Each wrack type and age was incubated to extract DOC. All leaves of both seagrass species 155 and the Laurencia thallus were lightly scraped with a razor blade to remove algal epiphytes. 
placed in $0.5 \mathrm{~L}$ of sterile, artificial seawater (ASW: Red Sea Salt ${ }^{\mathrm{TM}}$ at $35 \mathrm{ppt}$ ) in acid washed 2

L glass beakers. The beakers were sealed with scientific-grade rubber stoppers and incubated for $16 \mathrm{~h}$ at $18^{\circ} \mathrm{C}$ on shaker trays and with periodic, gentle agitation. Blanks were prepared as described above but with no wrack. After $16 \mathrm{~h}$, the leachate was filtered through a series of Whatman GFF filter papers and then a $0.45 \mu \mathrm{m}$, hydrophilic polypropylene membrane filter (Pall Life Sciences) and analysed for total DOC with a Shimadzu Total Organic Carbon Analyser 9000. Scraped leaves were used in the experiment to avoid DOC release from epiphytic algae. However, to test for any effect of scraping on DOC release, simultaneous incubations were performed on unscraped leaves with epiphytes gently removed by hand. Even with the removal of epiphytic algae and animals, a microbial biofilm is likely to remain on the leaf surface, which can reduce the flux of DOC to the surrounding waters through direct uptake (Maie et al. 2006). Consequently, the changes in DOC concentration of the incubating water are referred to as Net DOC release.

The initial leaching experiments indicated high release rates of DOC from fresh seagrass wrack in the first 1-2 weeks of aging. To obtain increased temporal resolution of early leaching rates, the experiment was repeated using $P$. sinuosa leaves to determine the change in release rate over this initial period of high DOC leaching. Three replicate leaf samples (180 g wet weight) were incubated in $1.4 \mathrm{~L}$ of ASW in acid washed $2 \mathrm{~L}$ glass beakers. A blank of ASW was incubated at the same time. Samples of the leachate were collected after 1, 3, 5, 7, 10, 14 days of incubation, and the ASW replaced each time. The leachate was filtered and analysed as described above.

\section{Characterization of DOC}

DOC composition was characterized by fractionation using open column chromatography following modified methods of Chow et al. (2004) and Cleveland et al. (2004). The leachate 
183

184

185

186

187

188

189

190

191

192

193

194

195

196

197

198

199

200

201

202

203

204

205

206

was fractionated into three components: 1) hydrophobic DOC (fulvic and humic acids;

Hughes, 2007) by retention on DAX-8 resin; 2) transphilic DOC, by retention on the XAD-4

resin; and 3) hydrophilic DOC, the eluent passing through the DAX-8 and XAD-4 column (Thurman \& Malcolm 1981). The hydrophilic fraction is composed predominantly of low molecular weight compounds, including carbohydrates and amino acids (Cleveland et al. 2004).

DAX-8 Superlite (Sigma-Aldrich) and XAD-4 Amberlite (Sigma Aldrich) resin columns were prepared in a similar manner, following the manufacturer's instructions. The resin was mixed with water (milli-Q) to form a slurry and poured into a glass column $(30 \mathrm{x} 1.5 \mathrm{~cm})$ fitted with a tap. The bed volume for the resin was approximately $20 \mathrm{~mL}$. The column was conditioned by passing $200 \mathrm{~mL}$ Milli-Q water though the column drop-wise, followed by six alternating washes of $0.1 \mathrm{M} \mathrm{NaOH}(40 \mathrm{~mL})$ and $0.1 \mathrm{M} \mathrm{HCl}(40 \mathrm{~mL})$, again eluted drop-wise. The final wash was with $0.1 \mathrm{M} \mathrm{HCl}$, to leave the column acidified.

The DOC leachate (200 mL) was acidified with 35\% $\mathrm{HCl}$ to $\mathrm{pH} 2$ then passed through the DAX-8 resin (dropwise or at $<3 \mathrm{~mL} \mathrm{~min}^{-1}$ ). The first $10 \mathrm{~mL}$ of eluent was discarded (as it was simply displaced acid). When most of the leachate had been applied to the column, $0.1 \mathrm{M}$ $\mathrm{HCl}$ (2 bed volumes or $40 \mathrm{~mL}$ ) was applied to the top of the column. The acid was passed through the column dropwise to elute all but the hydrophobic fraction. The eluent (leachate and acid) was then passed through the XAD-4 column in a similar manner, in this instance the acid eluting the hydrophilic fraction. A sample of de-ionised (Milli-Q) water was passed through the columns and treated in an identical way as the leachates to act as an analytical blank. 
The hydrophobic and transphilic fractions retained on the DAX-8 and XAD-4 resins, respectively, were elute with $0.1 \mathrm{M} \mathrm{NaOH}$. The volume of base added was typically 5 bed volumes $(100 \mathrm{~mL})$ or until the absorbance of the eluent at $254 \mathrm{~nm}$ was similar to the blank,

211 indicating an absence of DOC.

213 The total volume of each fraction was recorded. All pre-filtered leachate samples and 214 fractionated samples were acidified with 35\% $\mathrm{HCl}$ to $\mathrm{pH} 2$ and analyzed for total DOC with a 215 Shimadzu Total Organic Carbon Analyzer 9000. The UV absorbance for each of the acidified samples was also recorded at $254 \mathrm{~nm}$ on a Shimadzu UV-1601 spectrophotometer.

\section{Wrack composition on beaches}

The DOC leaching studies were conducted on wrack collected in sub-tidal habitats and incubated in submerged conditions, typical of sub-tidal seagrass wrack. Initial results showed differences in the net release of DOC from wrack of different ages. Since large amounts of wrack accumulate on beaches, we examined the age of beach-cast wrack to determine whether beach wrack was likely to have arrived while it was 'fresh' (and with higher net DOC release rates),and, therefore, whether the bulk of DOC leaching (and potential trophic subsidy) occurs in sub-tidal habitats or on beaches. The composition of beach wrack was determined at three sites on five occasions over the period of maximum wrack accumulation on beaches (May-Oct; McMahon et al., in review). Samples were collected at Forrest Beach,

229 Volunteer Marine Rescue and Geographe Sailing Club (Fig. 1) on $19^{\text {th }}-22^{\text {nd }}$ May, $9^{\text {th }}-11^{\text {th }}$ 230 June, $12^{\text {th }}-15^{\text {th }}$ August, $22^{\text {nd }}-25^{\text {th }}$ September and $20^{\text {th }}-22^{\text {nd }}$ October, 2008. At each site and time, four replicate wrack accumulations were sampled. About $0.001 \mathrm{~m}^{3}$ of wrack was collected from the surface of the accumulation with a quadrat and from the sediment immediately below the accumulation with a corer (90 mm I.D. x $10 \mathrm{~cm}$ deep). The wrack was 
234 rinsed to remove sand and sorted into categories based on the estimated age of wrack. Age

235 was defined as either old (no green leaves) or new (green leaves or stem) on the basis of their 236 colour: pilot work showed that moist leaves above the surface of the sediment turned brown 237 within 2 weeks ( $P$. sinuosa) or 2 - 4 weeks (A. antarctica) (Oldham et al., in review).

\section{Bioavailability of DOC}

240 We used a bacterial bioassay to test the bioavailability of the filtered DOC leachate produced by $P$. sinuosa leaves, $A$. antarctica leaves and stem, Laurencia sp. and fine particulate wrack during the $16 \mathrm{~h}$. incubations, using the methods of Cleveland et al. (2007). The response of a bacterial inoculum to the different DOC leachates was observed as growth rate over a $24 \mathrm{~h}$.

244 period.

Filtered DOC leachate $(200 \mathrm{~mL})$ was combined with a bacterial inoculum $(2 \mathrm{~mL})$ in acidwashed glass flasks, wrapped and capped in aluminum foil. A bacterial inoculum was created by combining $100 \mathrm{~g}$ of moist beach sediment, $100 \mathrm{~g}$ of moist wrack and $800 \mathrm{~mL}$ sterile artificial seawater. This was left in the dark for $24 \mathrm{~h}$ at $18^{\circ} \mathrm{C}$ and then filtered through a Whatman 3 filter paper with the filtrate used as the bacterial inoculum. For each DOC leachate, four replicates and four blanks (200 ml ASW + 2 ml bacterial inoculum) were incubated at $25^{\circ} \mathrm{C}$. Triplicate $1 \mathrm{~mL}$ sub-samples were taken after $0,3,18$ and $24 \mathrm{~h}$ of incubation and fixed with $0.5 \%$ glutaraldehyde for 15 min in the dark (Marie et al. 1997) then stored in liquid nitrogen until further processing. Heterotrophic bacterial cell counts were 255 determined on a FACS Canto II flow cytometer. Samples were diluted with TE buffer (1:50 256 dilution) and stained with SYBR Green I for 15 min. at $80^{\circ} \mathrm{C}$. Acquisition was run for 2 min 257 at a speed of $1 \mu \mathrm{s} \mathrm{s}^{-1}$. Data were stored as FCS 2.0 files and cell counts (cells $\mathrm{mL}^{-1}$ ) were 258 calculated using the CYTOWIN 4.3 software. 


\section{Statistical Analysis}

262

263

264

A one-way ANOVA was used to test for differences in the total amount of DOC released among different types of wrack, with wrack type as fixed factor. A two-way ANOVA was then used to test for differences among wrack types and DOC fraction on the total amount of DOC released, with wrack type and DOC fraction treated as fixed factors. A one-way ANOVA was used to test for significant effects of wrack age on the total DOC released, with age as fixed factor. A two-way ANOVA was then used to test for effects of wrack age and form of DOC on the amount of DOC released, with age and DOC fraction as fixed factors. A repeated measures ANOVA was used to test for significant effects of scraping on the release of DOC from leaves over time, with scraping a fixed factor.

The assumption of homogeneity of variances was tested using Cochran's test. When variances were heterogeneous, data were Ln- transformed, or arcsin-transformed for proportions and percentage values. Where significant main effects were detected, post-hoc comparisons (Tukey's) were conducted to determine the sources of significant variation.

\section{RESULTS}

\section{Amount and composition of DOC}

The net DOC leaching from wrack over 16 hours differed significantly among wrack types, with fresh algae (Laurencia sp.) leaching about four times the DOC released by fresh $P$. sinuosa leaves, six times that released by A. antarctica leaves, more than 11 times that released by A. antarctica stems and more than 90 times that released by the fine fraction of natural wrack accumulations (Table 1). The recovery of DOC after fractionation into hydrophobic, transphilic and hydrophilic fractions was high, ranging from 78-94\% (Table 1). 
For all wrack types, the hydrophilic fraction dominated the total DOC (37-68\%), followed by the hydrophobic fraction (17-31\%) and the transphilic fraction (4-11\%). Nonetheless, there were subtle, but significant, differences in the percentage contribution that hydrophobic and hydrophilic components made to the total DOC, but not the transphilic component (Table 1), reflected in a significant interaction between wrack type and DOC fraction (2-way ANOVA Wrack Type x DOC fraction d.f. $=8,59 ; \mathrm{p}<0.001)$. The proportion of DOC present as hydrophilic (and presumably the most bio-available) DOC was highest in fresh P. sinuosa 293 leaves (68\%) followed by Laurencia and Amphibolis tissues (53-61\%) and least in the fine 294 fraction of beach-cast wrack (37\%).

Influence of aging of P. sinuosa wrack on DOC leaching

The net DOC leaching from Posidonia sinuosa leaves declined with increasing age of the wrack (Table 2). Fresh and one week old leaves released similar amounts of DOC (>1400 mg $\mathrm{kg}^{-1}$ ) over $16 \mathrm{~h}$, at least 10 times the amount released after 2 weeks of aging and 20 times that released after 4 weeks. The composition of the leachate released by leaves of different ages varied subtly and not systematically (Table 2), with a significant interactive effect of wrack age and DOC fraction (2-way ANOVA, d.f. = 6,35, $\mathrm{p}<0.001$; and Table 2 for post-hoc pairwise comparisons). However, in all cases the leachate was dominated by the hydrophilic fraction (48-67\%), followed by the hydrophobic (16-27\%) and the transphilic (11-17\%) fractions.

DOC release during the first 14 days

308 The rate of net DOC released from fresh $P$. sinuosa leaves during the first 14 days was 309 affected by scraping (Fig 2), with a significant Time $x$ Scraping interaction $(\mathrm{p}<0.05)$. For 310 scraped leaves, the leaching rate $\left(A_{t}\right)$ was described by a single-stage exponential decay with 311 a half-life of 1.8 days: $A_{t}=752 \mathrm{e}^{(-0.317 t)}$. For unscraped leaves, the net release rate of DOC 
was describe by a two-stage model, with an increasing rate of DOC release for the first 5

313 days, after which the leaching rate was describe by a exponential decay with a half-life of

3141.65 days: $A_{t}=1610 \mathrm{e}^{(-0385 t)}$, which approached the decay curve for the scraped leaves.

316 Despite the differences in initial net DOC release rates, the total mass of DOC released

$317\left(\mathrm{M}_{\mathrm{DOC}}\right)$ from scraped and unscraped leaves was similar over the initial high release period

318 (first 5 days: $1650 \pm 122$ vs. $\left.1600 \pm 77.0 \mathrm{mg} \mathrm{kg}^{-1}\right)$ and then the full 14 days (1920 $\pm 131 \mathrm{vs}$.

$3191740 \pm 80.0 \mathrm{mg} \mathrm{kg}^{-1}$ ) of the experiment, indicating that the effect of scraping the leaves was

320 minimal in terms of quantity of DOC leached.

The accumulated mass released over the 14 days of incubation approached $2000 \mathrm{mg}$ (Fig 3), with the rate of release dramatically slowing by day 14 . Assuming that the mechanism of DOC release remained constantt over time, the curve fit to the full dataset (scraped and unscraped leaves, $\mathrm{M}_{\mathrm{DOC}}=716+470 \mathrm{Ln}(\mathrm{t})$ ) predicts that a further 1100 days (3 years) would be required to release the next $2000 \mathrm{mg}$.

\section{Composition of wrack on beaches}

The wrack accumulating on Geographe Bay beaches was typically dominated by old material

(Fig 4). In May, the period just prior to the first autumn - winter storms, the wrack on the sand (generally $>90 \%$ ). During the winter storm period (June - September) the proportion of fresh wrack increased in both zones, reaching $25-30 \%$ at the surface of accumulations but was always less than $10 \%$ in the sediment layer below accumulations. By October (spring), the proportion of fresh wrack had declined in all accumulations, approaching $5 \%$ in the surface layer and negligible in the sediment layer. 


\section{Bioavailability of DOC leachates}

339 For leachates from all types of fresh wrack material, there were significant exponential 340 increases in bacterial abundance over time following inoculation (Fig 5; Table 3; in all cases $341 \mathrm{p}<0.001$. The Fine Fraction from beach cast wrack also showed a significant increase in 342 bacterial abundance over time ( $<<0.05)$, though the rate of increase was much smaller. In 343 leachate from one month old Posidonia leaves, there was no significant increase in bacterial 344 abundance over time. In all cases, when the number of bacteria in the blank incubations was 345 plotted against time the slope was not significantly different to zero, indicating little or no 346 bacterial growth, except for the Fresh Posidonia and Laurencia leachate incubations, where 347 there was a significant exponential decay in bacterial abundance.

The age of Posidonia wrack affected the ability of the leachate to support bacterial growth. For leachate from fresh Posidonia leaf material, the linear increase in bacterial abundance over a $24 \mathrm{~h}$ period had an average slope of $2.04 \times 10^{5}$ cells $^{-1}$. For the leachate from 4 weeks old Posidonia leaves, bacterial abundance increased for the first 18 hours, though the slope over this period was less than half that in the leachate from fresh leaves $\left(9.20 \times 10^{4}\right.$ cells $\left.\mathrm{h}^{-1}\right)$, and declined thereafter.

\section{DISCUSSION}

\section{Effect of wrack type on DOC release}

Total net DOC released varied among types of wrack (algae $>$ Posidonia leaves $>$ Amphibolis leaves $>$ Amphibolis stems $>$ fine fraction). This is consistent with studies that found release rates were higher from algae than seagrasses (e.g. Brylinsky, 1977). Algae have less structural 
difference. Within the different types of seagrass wrack there were also differences in release

365

rates of DOC. Fresh Posidonia leaves had the largest release rate of DOC, followed by A. antarctica leaves and then stems. The stems of Amphibolis are vertical rhizomes and serve as a major storage organ for carbohydrates. In the closely related species Amphibolis griffithii, soluble sugars account for $15-20 \%$ DW, and starches account for $2-3 \%$ DW of the rhizome (Lavery et al. 2009). On this basis, we might expect higher fluxes of soluble carbohydrate compounds from the stems than the leaves. However, the lower net release rate for stems may reflect higher levels of other soluble compounds in the leaves, especially proteins associated with photosynthesis, and stronger barriers to diffusion, since stems are highly lignified and contain large amounts of vascular tissue. This may also explain the differences among leaves, since Posidonia sinuosa leaves and those of A. griffithii typically have similar levels of soluble sugars and starches $(P$. sinuosa $=2-4 \%$ DW soluble sugars and 5-10\% starches; Collier, et al. 2009); A. griffithii = 5-15\% soluble sugars and 2-3\% starch; Lavery et al. 2009).

The relatively low release rates from aged Posidonia leaves (4 weeks old) and the fine particulate fraction of wrack (at least 2 months old) reflects the effect of aging on DOC release and the significant loss of DOC which occurs in the first few days of leaching. However, despite the low rate of bacterial growth on leachate from the 4 weeks old Posidonia leaves, the initial growth over 18 hours confirms that the DOC leachate was bioavailable.

The decline in bacterial biomass after 18 hours indicates that it was more likely a function of the mass of DOC in the leachate than the composition that affected bacterial growth.

The composition of the DOC leached from different species of wrack was similar. This may partly reflect the level of resolution in our chemical characterisation of the leachates. The high \% recovery of DOC following fractionation gives confidence that we have not underestimated a significant portion of the DOC. Maie et al. (2006) found differences in 
concentrations of sugars and phenols in leachate from a range of aquatic plants they studied.

391 However, the plants they studied covered a wide phylogenetic range, from algal periphyton to freshwater macrophytes, mangroves and seagrasses. In comparison, our wrack was all derived from seagrasses, with the exception of the alga Laurencia.

The similarity in leachate quality from all wrack types, including that of aged wrack, indicates that the quality of DOC that seagrass wrack contributes to recipient habitats is likely to be similar, irrespective of the type or age of the wrack, though the mass contributed will decline rapidly with age. It was surprising that the hydrophilic portion (which contains sugars, amino acids, small molecular weight fatty acids and other compounds likely to be more labile) continued to form a significant proportion (more than 50\%) of the DOC leached from aged $P$. sinuosa and the fine fraction. It is not clear whether, in the older wrack, the low molecular weight component is derived directly from the wrack, or is contained in exudates from bacteria growing on the wrack or in suspension. In any case, this makes little difference in terms of the potential benefit of the input to recipient ecosystems. If it is derived from exudates of bacteria growing on the wrack, then it is possible that this input of readily bioavailable DOC could persist for months, though at a very slow rate.

\section{Mass \& Timescale of DOC Release}

The release rate of DOC declined rapidly with age of Posidonia wrack. About 50\% (2000 mg $\mathrm{kg}^{-1} \mathrm{FW}$ wrack) was released in the first 14 days. Assuming that the mechanism of DOC release remains constant over the decay period of the wrack, it would take in the order of 412 thousands of days to release the next $2000 \mathrm{mg} \mathrm{kg}^{-1} \mathrm{FW}$ wrack. This assumption may not be 413 the case but, nonetheless, it is clear that the rate of DOC release will fall dramatically after the 414 first days. The Posidonia leaves used in our studies contained about 33\% carbon DW or 11\% 415 FW (using a DW;FW ratio of 0.34; unpublished data) so the total mass of carbon released 
over 14 days was about $1.8 \%$ of the leaf carbon, and if we project out to 2000 days, $3.6 \%$ of

417 the leaf carbon. These values are similar to the total fixed carbon lost through DOC excretion reported for Posidonia oceanica (Velimirov 1986) but much less than the $48 \%$ estimated by Kirkman \& Reid (1979) for Posidonia australis, which has very similar leaf structure to $P$. sinuosa (Cambridge \& Kuo 1982). Kirkman \& Reids’ (1979) estimate was likely to have 421 severely over-estimated the leaching of DOC from leaves. They used leaves with necrotic tissue and with a full complement of epiphytes which would have contributed to DOC leakage, and they measured the rates over two hours, which are likely to produce much higher estimates of loss that would occur for aged wrack tissue, as shown by our results.

Temporal variation in DOC release rates have been reported for other seagrasses. Velimirov (1986) found that the young, green portions of Posidonia oceanica leaves released negligible amounts of DOC but high loss was observed for older, brown leaves, while the rate of DOC leaching from Thalassia testudinum leaves declined exponentially with age, with $84 \%$ of the DOC leached in the first two weeks (Maie et al. 2006). In our case, the initial rate of DOC release was enhanced by scraping leaves to remove epiphytes. This could be due to the removal of epiphytes or damage to the leaf surface. Epiphytic organisms reduce the release of DOC from seagrass leaves to surrounding water (Velimirov 1986, Wetzel \& Penhale 1979), presumably through assimilation of the DOC. Scraping is also likely to disrupt the tough cuticle and thick epidermal leaves of $P$. sinuosa (Cambridge \& Kuo, 1982), enhancing diffusive losses of cellular DOC. However, this effect was limited mainly to day 1 , with the total mass of DOC released over the first 5 days (the period of highest initial release rates) similar in both types of leaf, providing confidence that scraping had little effect on the total amount of DOC released beyond the first day. Despite the potential for scraping to introduce an experimental artefact, it may be representative of the condition of naturally shed leaves

441 which will have damage to the leaf surface, particularly the necrotic upper part of the leaves, 
442 through the action of grazers and abrasion by sediments as they are transported in bedload and 443 suspended transport.

The bacterial growth in the assays demonstrates the bioavailability of the leachate DOC released from fresh seagrass and algae, with exponential increases in abundance indicating

447 bacterial growth. Bacteria grown on seagrass DOC leachate can rapidly be converted into 448 bacterial aggregates that are consumed by ciliates and flagellates at a much faster rate than the 449 residual particulate organic carbon (Robertson et al. 1982). We did not enumerate the bacteria on the surface of the wrack, but these typically are much more abundant that bacteria in suspension.

\section{Relative contribution of wrack to DOC in Geographe Bay}

454 While it was beyond the scope of this study to produce a full DOC budget for Geographe Bay, sufficient information is available to compare the potential contribution of wrack with some other sources of DOC (Table 1) to the study area. Oldham et al. (2010) estimated a total annual wrack production of 16,900 t DW of Posidonia leaf wrack and 15, 700 t of Amphibolis wrack from this region (i.e. an area of $60 \mathrm{~km}^{2}$ with an average depth of $5 \mathrm{~m}$ - the area of seagrass coverage to the $10 \mathrm{~m}$ depth contour). At the initial DOC release rates recorded in our study, this mass of wrack would contribute $191 \mathrm{~kg}$ of DOC to the study region in one day. Actively growing phytoplanktton can leak between $0.0005-0.055$ pmol DOC cell ${ }^{-1} \mathrm{~d}^{-1}$

462 (Biddanda \& Benner 1997). Coastal waters to the north of Geographe Bay typically have 463 about 91,000 cells $\mathrm{L}^{-1}$ of phytoplankton (Hanson et al. 2006). Assuming a similar cell count 464 in Geographe Bay, phytoplankton in the study area would, at most, contribute $0.19-21 \mathrm{~kg}$ DOC per day, between 1 and 3 orders of magnitude less than seagrass wrack. 
Velimirov (1986) compared the DOC release from healthy, living and scenescent seagrass

469 leaves; healthy leaves released $0.2 \%$ of that released by scenescent leaves. However, the

470 biomass of living meadow is much higher than that of wrack. Assuming a release rate

471 comparable to that given by Velimirov for Posidonia oceanica $\left(0.006 \mathrm{mg} \mathrm{DOC} \mathrm{g}^{-1} \mathrm{~h}^{-1}\right)$ and

472 using McMahon et al.’s (1997) reported biomass for Posidonia sinuosa in Geographe Bay

473 (115-470 $\mathrm{g} \mathrm{dw} \mathrm{m}^{-2}$ ), live seagrass in the study area would provide 990 - $4000 \mathrm{~kg}$ DOC per

474 day to the study area, 10-40 times that of wrack. Of course, this is a fixed source of DOC,

475 compared with the more mobile nature of wrack, which permits inter-habitat connectivity.

Surface beach sands can be a significant source of DOC to the water column in high-energy environments, with a net flux of 4-22 mmol DOC $\mathrm{m}^{-2} \mathrm{~d}^{-1}$ (Heymans \& McLachlan 1996,

D’Andrea et al. 2002, Avery et al. 2012). Geographe Bay has an approximately $0.5 \mathrm{~m}$ diurnal

480 tide range and a mean beach slopes of about $0.06 \mathrm{~m} \mathrm{~m}^{-1}$ (Oldham et al. 2010). Using the 481 lower slope estimate, over the $30 \mathrm{~km}$ stretch of beach an area of $2.5 \times 10^{5} \mathrm{~m}^{-2}$ of beach face would be inundated each day, providing an estimated flux of DOC in the order of 12-66 kg DOC $\mathrm{d}^{-1}$. While significant, this is a smaller source than, and is likely to be most significant to the surf zone adjacent to the beach unlike wrack, which can be transported and gradually release DOC over a wider area.

\section{Implications for Trophic connectivity}

488 The exponential-decay model of DOC release from $P$. sinuosa leaves indicates that there will 489 be significant temporal variation in the release of DOC from leaves shed by plants, with 490 significant implications for trophic connectivity. Wrack is constantly being produced in seagrass meadows, but in the case of Posidonia and Amphibolis leaves significant water velocities, in excess of $0.15 \mathrm{~m} \mathrm{~s}^{-1}$, are required to suspend wrack, allowing it to be transported away from the meadow (Oldham et al. in review). Typically, this results in wrack 
accumulating in offshore meadows during quiescent periods (spring through to early autumn

495 in our study site) and leaves being transported to beaches and other habitats during storm events (McMahon et al., in review), typically in autumn and winter. Leaves shed in spring and summer may, therefore, slowly degrade within the meadow for several weeks or months, with the majority of DOC released within the meadow itself. Adjacent habitats will only receive wrack in a high DOC-leaching phase under two scenarios: 1) during unusual storm events which are sufficiently energetic to dislodge and transport living material and when fresh wrack may constitute a significant portion of the total; and 2) during normal autumnwinter storms, when it will only constitute a small proportion of the total wrack exported (i.e. that shed in the previous two weeks).

The above suggests that in our system and outside of storm events, when the timescale of leaching is typically much faster than the timescale of transport, wrack may be of limited value in supporting trophic subsidies. However, we have noted relatively high DOC concentrations in porewaters beneath wrack accumulations. While fresh wrack was never the dominant component of wrack accumulations, it frequently accounted for $25-30 \%$ of the mass during winter (when storm conditions dominate). During this time, beach accumulations can persist for several weeks reaching biomasses of $4 \mathrm{~kg} \mathrm{~m}^{-2}$ under natural conditions but as much as $19 \mathrm{~kg} \mathrm{~m}^{-2}$ in areas affected by coastal structures (McMahon in prep). Assuming $4 \mathrm{~kg} \mathrm{~m}^{-2}$ of wrack with $30 \%$ fresh material approximately $4.1 \mathrm{~g}$ of DOC $\mathrm{m}^{-2}$ would be released over two

514 weeks, which our data shows is capable of supporting bacterial growth. Thus, while seagrass 515 wrack may have relatively little value as a source of trophic connectivity during periods of quiescent hydrodynamics, it may still be important during periods of higher energy and faster transport, leading to the formation of biogeochemical hot moments (sensu McClain et al. 2003). Furthermore, under quiescent hydrodynamics, seagrass detritus may contribute, even if at slow DOC release rates, to the sedimentary organic carbon pool of offshore habitats 
520 including oligotrophic unvegetated habitats, as suggested by Ziegler \& Benner (1999). This

521 could also apply to beaches and other recipient habitats if the wrack is buried and therefore

522 can persist in these habitats for sufficiently long periods to allow an accumulation of DOC.

523 This demonstrates a complex interaction of timescales of transport (or residence times) and

524 timescales of leaching which must be undertaken into account when considering the potential

525 for trophic subsidies.

\section{Conclusions}

We conclude that Posidonia sinuosa and Amphibolis antarctica seagrass wrack leaches bioavailable DOC. We also conclude that, for $P$. sinuosa, there is an initial rapid release of

530 DOC within the first days-weeks followed by an extended period of low release rates. As 531 similar tmecourse of DOC release have been shown for other seagrasses such as P. oceanica 532 (Velimirov 1986) and Thalassia testudinum (Maie et al. 2006), it is likely that wrack from 533 many species of seagrass will demonstrate similar patterns of DOC release. Despite 534 differences in the rate of DOC release from different types and ages of wrack, the 535 composition was similar and it was bioavailable even when released from old wrack, though 536 the amount released would limit bacterial growth. Given the known consumption of bacterial 537 aggregates by higher levels of the foodweb, the leaching of DOC is one means of recycling 538 the nutrients in seagrass detritus. The interaction of the timescales of transport and the 539 timescale of leaching will be critical in determining the value of wrack as a vector for trophic 540 subsidies. When fresh wrack is released during periods of rapid hydrodynamic transport, it 541 has the potential to release most of its DOC into recipient habitats. However, during 542 quiescent periods, the rapid leaching will result in most of the DOC being recycled within the 543 seagrass meadow. Further work is required to determine the importance of bacterial growth 544 on the surface of wrack and in suspension as a sink for seagrass DOC, and the efficiency of its 545 subsequent incorporation into the food web of recipient ecosystems. 
547 Acknowledgements

548 We thank Dr Kathy Heel for assistance with the flow cytometry and Dragana Vesolinovic for

549 assistance with the GC-FID analyses. Funding for this work was provided by the Shire of

550 Busselton and the Western Australian Department of Transport. We thank James Holder for

551 his assistance throughout the project.

552 
Avery GB, Kieber RJ, Taylor KJ, Dixon JL (2012) Dissolved organic carbon release from surface sand of a high energy beach along the Southeastern Coast of North Carolina, USA. Marine Chemistry 132-133:23-27

Barrón C, Duarte C (2009) Dissolved organic matter release in a Posidonia oceanica meadow. Marine Ecology Progress Series 374:75-84

Benner R, Peele ER, Hodson RE (1986) Microbial utilization of dissolved organic matter from leaves of the red mangrove, Rhizophora mangle, in the fresh creek estuary, Bahamas. Estuarine Coastal and Shelf Science 23:607-619

Biddanda B, Benner R (1997) Carbon, nitrogen, and carbohydrate fluxes during the production of particulate and dissolved organic matter by marine phytoplankton. Limnology and Oceanography 42:506-518

Brylinsky M (1977) Release of dissolved organic matter by some marine macrophytes. Marine Biology 39:213-220

Cambridge M, Kuo J (1982) Morphology, anatomy and histochemistry of the Australian seagrasses of the genus Posidonia Konig (Posidoniaceae) III . Posidonia sinuosa Cambridge \& Kuo. Aquatic Botany 14:1-14

Cebrian J, Duarte CM (2001) Detrital stocks and dynamics of the seagrass Posidonia oceanica (L.) Delile in the Spanish Mediterranean. Aquatic Botany 70:295-309

Chow CWK, Fabris R, Drikas M (2004) A rapid fractionation technique to characterise natural organic matter for the optimisation of water treatment processes. The Journal of Water Supply 53:85-92

Cleveland CC, Neff JC, Townsend AR, Hood E (2004) Composition, dynamics and fate of leached dissolved organic matter in terrestrial ecosystems: Results from a decomposition experiment. Ecosystems 7:275-285

Cleveland CC, Nemergut DR, Schmidt SK, Townsend AR (2007) Increases in soil respiration following labile carbon additions linked to rapid shifts in soil microbial community composition. Biogeochemistry 82:229-240

Collier CJ, Lavery PS, Ralph PJ, Masini RJ (2009) Shade-induced response and recovery of the seagrass Posidonia sinuosa. Journal of Experimental Marine Biology and Ecology 370:89-103

Crawley KR, Hyndes GA, Vanderklift MA, Revill AT, Nichols PD (2009) Allochthonous brown algae are the primary food source for consumers in a temperate, coastal environment. Marine Ecology Progress Series 376:33-44

D'Andrea AF, Aller RC, Lopez GR (2002) Organic matter flux and reactivity on a South Carolina sandflat: The impacts of porewater advection and macrobiological structures. Limnology \& Oceanography 47:1056-1070 
Doropoulos C, Hyndes GA, Lavery PS, Tuya F (2009) Dietary preferences of two seagrass inhabiting gastropods : Allochthonous vs autochthonous resources. Estuarine, Coastal and Shelf Science 83:13-18

Ducker SC, Foord NJ, Knox RB (1977) Biology of Australian Seagrasses: the Genus Amphibolis C. Agardh (Cymodoceaceae. Australian Journal of Botany:67-95

Green EP, Short FT (2003) World Atlas of Seagrasses. UNEP-WCMC, Cambridge

Hanson C, Clementson L, Thompson P (2006) Phytoplankton community structure. In: Keesing JK, Heine JN, Babcock RC, Craig PD, Koslow JA (eds) Strategic research Fund for the Marine Environment Final Report. Volume 2: The SRFME core projects. Strategic research Fund for the Marine Environment, CSIRO, p 71-80

Heymans JJ, McLachlan A (1996) Carbon Budget and Network Analysis of a High-energy Beach/Surf-zone Ecosystem. Estuarine Coastal and Shelf Science 43:485-505

Hyndes GA, Lavery PS (2005) Does transported seagrass provide an important trophic link in unvegetated, nearshore areas? Estuarine Coastal and Shelf Science 63:633-643

Ince R, Hyndes GA, Lavery PS, Vanderklift MA (2007) Marine macrophytes directly enhance abundances of sandy beach fauna through provision of food and habitat. Estuarine Coastal and Shelf Science 74:77-86

Kaldy JE, Eldridge PM, Cifuentes LA, Jones WB (2006) Utilization of DOC from seagrass rhizomes by sediment bacteria : 13C-tracer experiments and modeling. Marine Ecology Progress Series 317:41-55

Kirkman H, Kendrick GA (1997) Ecological significance and commercial harvesting of drifting and beach-cast macro-algae and seagrasses in Australia : a revie. Journal of Applied Phycology 9:311-326

Kirkman H, Reid D (1979) A study of the role of the seagrass Posidonia australis in the carbon budget of an estuary. Aquatic Botany 7:173-183

Klumpp DW, Vandervalk A (1984) Nutritional quality of seagrasses (Posidonia australis and Heterozostera tasmanica) - comparison between species and stages of decomposition. Marine Biology Letters:67-83

Lavery PS, Mcmahon K, Mulligan M, Tennyson A (2009) Interactive effects of timing , intensity and duration of experimental shading on Amphibolis griffithii. Marine Ecology 394:21-33

Lavery PS, Vanderklift MA (2002) A comparison of spatial and temporal patterns in epiphytic macroalgal assemblages of the seagrasses Amphibolis griffithii and Posidonia coriacea. Marine 236:99-112

Maie N, Jaffé R, Miyoshi T, Childers DL (2006) Quantitative and qualitative aspects of dissolved organic carbon leached from senescent plants in an oligotrophic wetland. Biogeochemistry 78:285-314 
Marie D, Partensky F, Jacquet S (1997) Enumeration and cell cycle analysis of natural populations of marine picoplankton by flow cytometry using the nucleic acid stain SYBR Green. Applied and Environmental Microbiology 63:186-193

Mateo MA (2010) Beach-Cast Cymodocea nodosa Along the Shore of a Semienclosed Bay: Sampling and Elements to Assess Its Ecological Implications. Journal of Coastal Research 262:283-291

Mateo MA, Cebrian J, Dunton K, Mutchler T (2006) Carbon Flux in Seagrass Ecosystems. In: Larkum A, Orth R, Duarte C (eds) Seagrasses: Biology, Ecology and Conservation. Springer-Verlag, Netherlands, p 159-192

McClain ME, Boyer EW, Dent CL, Gergel SE, Grimm NB, Groffman PM, Hart SC, Harvey JW, Johnston C a., Mayorga E, McDowell WH, Pinay G (2003) Biogeochemical hot spots and hot moments at the interface of terrestrial and aquatic ecosystems. Ecosystems 6:301-312

McMahon K, Young E, Montgomery S, Cosgrove J, Wilshaw J, Walker DI (1997) Status of a shallow seagrass system , Geographe Bay, south-western Australia. Journal of the Royal Society of Western Australia 80:255-262

Moore TN, Fairweather PG (2006) Decay of multiple species of seagrass detritus is dominated by species identity, with an important influence of mixing litters. Oikos 114:329-337

Moriarty DJW, Pollard PC (1982) Diel variation of bacterial productivity in seagrass (Zostera capricorni) beds measured by rate of thymidine incorporation into DNA. Marine Biology 173:165-173

Oldham CE, Lavery PS, McMahon K, Pattiratchi C, Chiffings TW (2010) Seagrass wrack dynamics in Geographe Bay, Western Australia. Nedlands, Australia

Prado P, Collier C, Lavery PS (2008) $13 \mathrm{C}$ and $15 \mathrm{~N}$ translocation within and among shoots in two Posidonia species from Western Australia. Marine Ecology Progress Series 361:6982

Robertson AI, Lenanton RCJ (1984) Fish community structure and food chain dynamics in the surfzone of sandy beaches: the role of detached macrophyte detritus. Journal of Experimental Marine Biology and Ecology 84:265-283

Robertson M, Mills A, Zieman J (1982) Microbial synthesis of detritus-like particulates from dissolved organic carbon released by tropical seagrasses. Marine Ecology Progress Series 7:279-285

Smit AJ, Brearley A, Hyndes GA, Lavery PS, Walker DI (2005) Carbon and nitrogen stable isotope analysis of an Amphibolis griffithii seagrass bed. Estuarine Coastal and Shelf Science 65:545-556

Smit AJ, Brearley A, Hyndes G a., Lavery PS, Walker DI (2006) $\delta 15 \mathrm{~N}$ and $\delta 13 \mathrm{C}$ analysis of a Posidonia sinuosa seagrass bed. Aquatic Botany 84:277-282 
665 Thurman EM, Malcolm RM (1981) Preparative isolation of aquatic humic substances.

666 Environmental Science and Technology 15:463-466

667 Velimirov B (1986) DOC dynamics in a Mediterranean seagrass system. Marine Ecology

668 Progress Series 28:21-41

669 Wetzel RL, Penhale PA (1979) Transport of carbon and excretion of dissolved organic carbon

670 by leaves and roots/rhizomes in seagrasses and their epiphytes. Aquatic Botany 6:149-

$671 \quad 158$

672 Ziegler S, Benner R (1999) Dissolved organic carbon cycling in a subtropical seagrass-

673 dominated lagoon. Marine Ecology Progress Series 180:149-160

674

675 
Table 1 Dissolved organic carbon composition in leachates derived from different wrack material (means $\pm \mathrm{sd}$ ). Within each class of DOC (totals, hydrophobic, transphilic and hydrophilic), shared subscript letters indicate no significant differences among wrack types $(\alpha=0.05)$. Posidonia $=P$. sinuosa, Amphibolis $=$ A. antarctica $;$ Fine fraction $=0.1-1.0$ $\mathrm{mm}$ size class of natural wrack accumulations.

681

\begin{tabular}{lcc}
\hline Wrack Type & DOC released in $16 \mathbf{~ h}$ & DOC \\
& $\left(\mathrm{mg} \mathrm{kg}^{-1} \mathrm{FW}\right.$ wrack; $\mathrm{n}=4$ in all cases $)$ & Recovery
\end{tabular}

TOTAL Hydrophobic Transphilic Hydrophilic

\begin{tabular}{|c|c|c|c|c|c|}
\hline Fresh Laurencia & $6749 \pm 278$ a & $\begin{array}{r}1998 \pm 64 \\
30 \%{ }_{a}\end{array}$ & $\begin{array}{r}675 \pm 95 \\
10 \%{ }_{a}\end{array}$ & $\begin{array}{r}3554 \pm 213 \\
53 \%_{a}\end{array}$ & $93 \%$ \\
\hline \multirow{2}{*}{$\begin{array}{l}\text { Fresh Posidonia } \\
\text { leaves }\end{array}$} & $1724 \pm 76_{\mathrm{b}}$ & $298 \pm 14$ & $138 \pm 6$ & $1173 \pm 58$ & $93 \%$ \\
\hline & & $17 \%_{b}$ & $8 \%_{b}$ & $68 \%_{b}$ & \\
\hline \multirow{2}{*}{$\begin{array}{l}\text { Fresh Amphibolis } \\
\text { leaves }\end{array}$} & $1102 \pm 24_{c}$ & $284 \pm 26$ & $48 \pm 4$ & $676 \pm 21$ & $91 \%$ \\
\hline & & $26 \%_{b}$ & $4 \%_{b c}$ & $61 \%_{c}$ & \\
\hline \multirow{2}{*}{$\begin{array}{l}\text { Fresh Amphibolis } \\
\text { stems }\end{array}$} & $588 \pm 31_{\mathrm{d}}$ & $180 \pm 13$ & $58 \pm 4$ & $312 \pm 29$ & $94 \%$ \\
\hline & & $31 \%_{c}$ & $10 \%_{b c}$ & $53 \%_{d}$ & \\
\hline Fine fraction & $74 \pm 1_{\mathrm{e}}$ & $\begin{array}{l}22 \pm 3 \\
30 \%_{d}\end{array}$ & $\begin{array}{r}8 \pm 5 \\
11 \%_{c}\end{array}$ & $\begin{array}{c}27 \pm 1 \\
37 \%_{e}\end{array}$ & $78 \%$ \\
\hline
\end{tabular}

682

683 
Table 2 Dissolved organic carbon composition of leachate from $P$. sinuosa leaves of different ages.

689 ANOVA revealed a significant interaction of Age and DOC fraction $(\mathrm{p}<0.001)$. Shared subscript

690 letters indicate no significant difference in mass of DOC released (Tukey’s test; $p>0.05$ ) among

691 treatments within each class of DOC.

692

\begin{tabular}{|c|c|c|c|c|c|}
\hline \multirow[t]{2}{*}{ Age } & \multicolumn{4}{|c|}{$\begin{array}{l}\text { DOC release over } \mathbf{1 6} \mathbf{h} \\
\left(\mathrm{mg} \mathrm{kg}^{-1} \mathrm{FW} \text { wrack }\right)\end{array}$} & \multirow[t]{2}{*}{$\begin{array}{c}\text { DOC } \\
\text { Recovery }\end{array}$} \\
\hline & TOTAL & Hydrophobic & Transphilic & Hydrophilic & \\
\hline Fresh1 & $1419 \pm 93$ a & $\begin{array}{r}223 \pm 18 \\
16 \%{ }_{a}\end{array}$ & $\begin{array}{r}181 \pm 17 \\
13 \%_{a}\end{array}$ & $\begin{array}{r}855 \pm 45 \\
60 \%{ }_{a}\end{array}$ & $89 \%$ \\
\hline 1 week old & $1627 \pm 192 \mathrm{a}$ & $\begin{array}{r}417 \pm 13 \\
26 \%\end{array}$ & $\begin{array}{r}277 \pm 32 \\
17 \%_{a}\end{array}$ & $\begin{array}{r}783 \pm 120 \\
48 \%\end{array}$ & $91 \%$ \\
\hline 2 weeks old & $133 \pm 17 b$ & $\begin{array}{l}36 \pm 4 \\
27 \%_{b}\end{array}$ & $\begin{array}{l}19 \pm 4 \\
14 \%_{a}\end{array}$ & $\begin{array}{l}67 \pm 7 \\
50 \%_{b}\end{array}$ & $91 \%$ \\
\hline 4 weeks old & $67 \pm 2_{c}$ & $\begin{array}{l}12 \pm 1 \\
18 \%_{c}\end{array}$ & $\begin{array}{r}7.2 \pm 0.2 \\
11 \%_{a}\end{array}$ & $\begin{array}{l}45 \pm 1 \\
67 \%{ }_{a}\end{array}$ & $96 \%$ \\
\hline
\end{tabular}

693

694

695 
698 Table 3 Exponential curve fits describing the change in abundance of bacterial cell abundance over $69924 \mathrm{hr}$ in leachates from different types of wrack following bacterial inoculation. * = significant at $700 \mathrm{p} \geq 0.05 ; * * \mathrm{p} \leq 0.01$. In all cases, $\mathrm{x}=$ time in hours.

701

702

\begin{tabular}{llrr}
\hline Wrack Type & Correlation & r & p \\
\hline Posidonia leaf (Fresh) & $4.54 \times 10^{5} \mathrm{e}^{0.109 \mathrm{x}}$ & 0.95 & $* * *$ \\
Laurencia (Fresh) & $1.65 \times 10^{6} \mathrm{e}^{0.101 \mathrm{x}}$ & 0.90 & $* * *$ \\
Amphibolis leaf (Fresh) & $1.26 \times 10^{6} \mathrm{e}^{0.076 \mathrm{x}}$ & 0.89 & $* * *$ \\
Amphibolis stem (Fresh) & $1.23 \times 10^{6} \mathrm{e}^{0.086 \mathrm{x}}$ & 0.97 & $* * *$ \\
Posidonia (Old) & $3.92 \times 10^{4} \mathrm{e}^{0.129 \mathrm{x}}$ & 0.34 & nsd \\
Fine Fraction & $7.64 \times 10^{4} \mathrm{e}^{0.084 \mathrm{x}}$ & 0.51 & $*$ \\
Blank (Fresh Posidonia & $9.58 \times 10^{4} \mathrm{e}^{-0.011 \mathrm{x}}$ & - & $* * *$ \\
\& Laurencia) & & 0.83 & \\
\hline
\end{tabular}




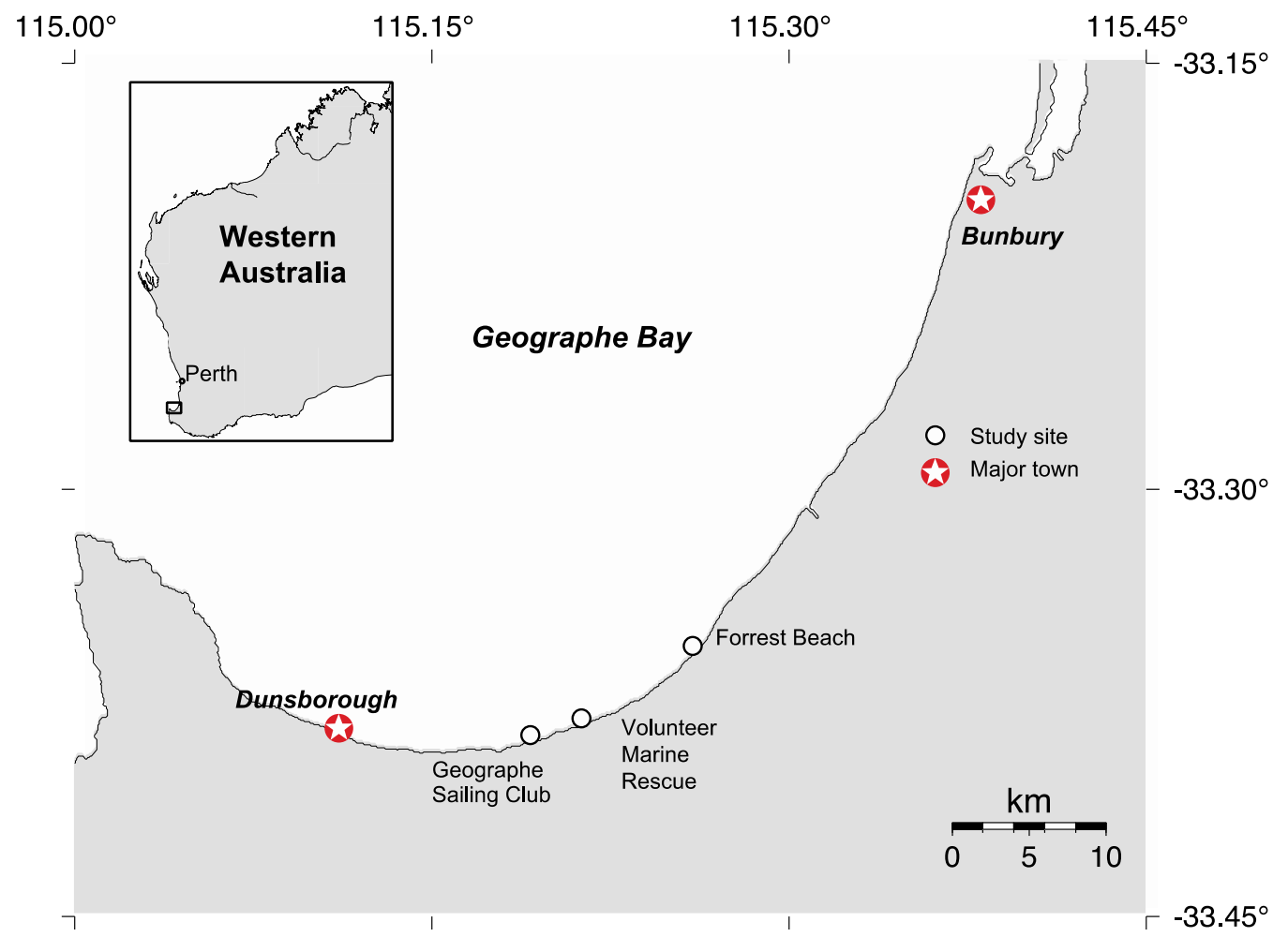

705

706

707 Figure 1 Map of Geographe Bay, Western Australia, showing the location of the three sites used to 708 sample beach wrack composition.

709 


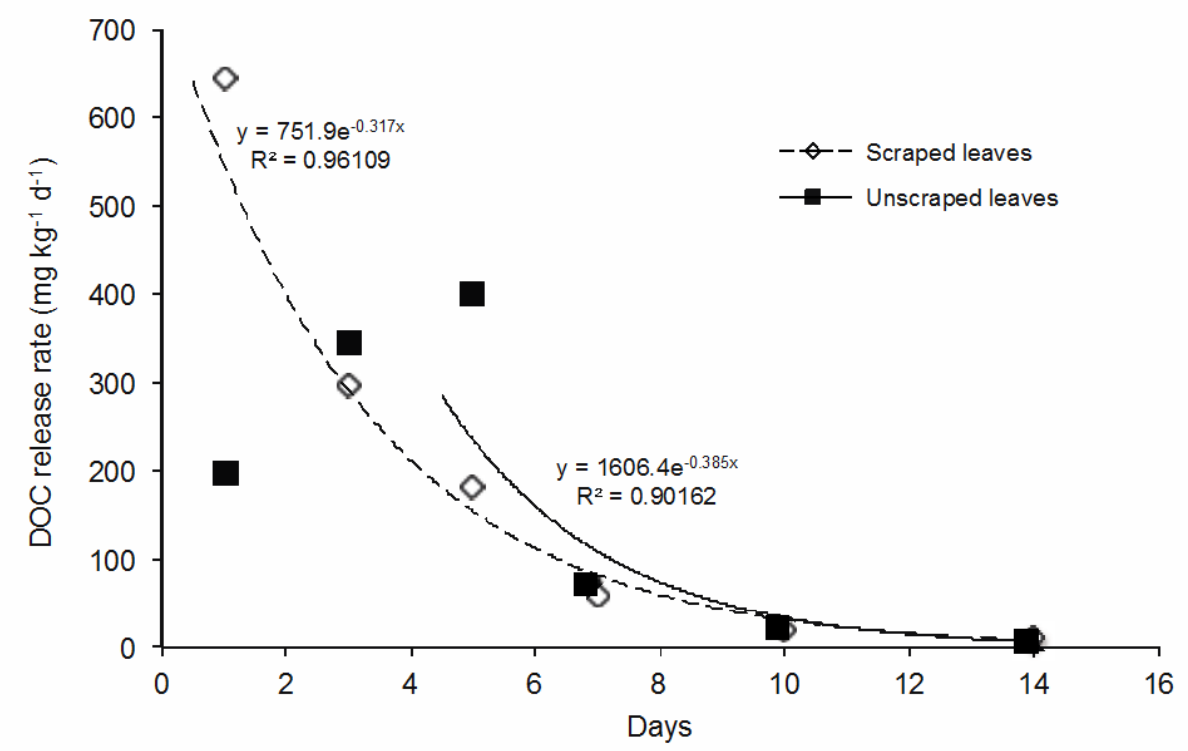

715 Figure 2 Net DOC release rates from scraped and unscraped $P$. sinuosa leaves during 14-

716 day incubations. The regression for unscraped leaves is for days 5-14. 

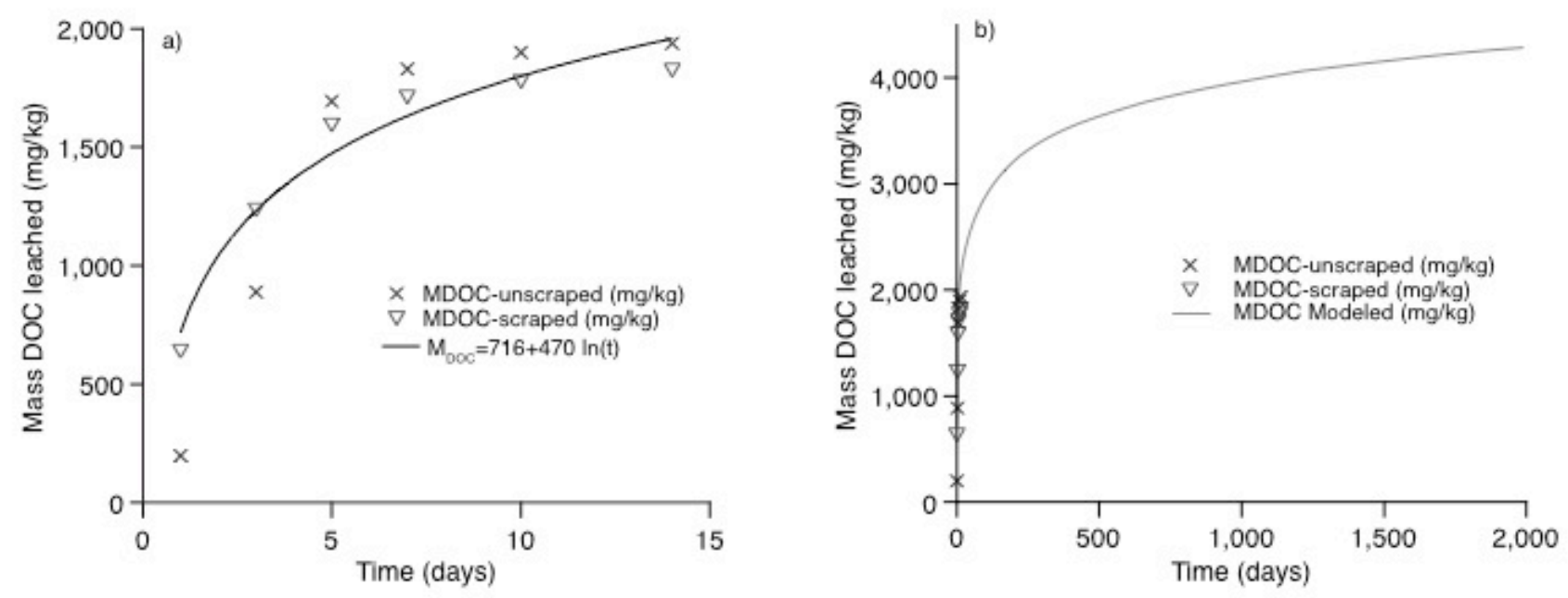

724

725

Figure 3 Cumulative net mass of DOC released over time

726

727 


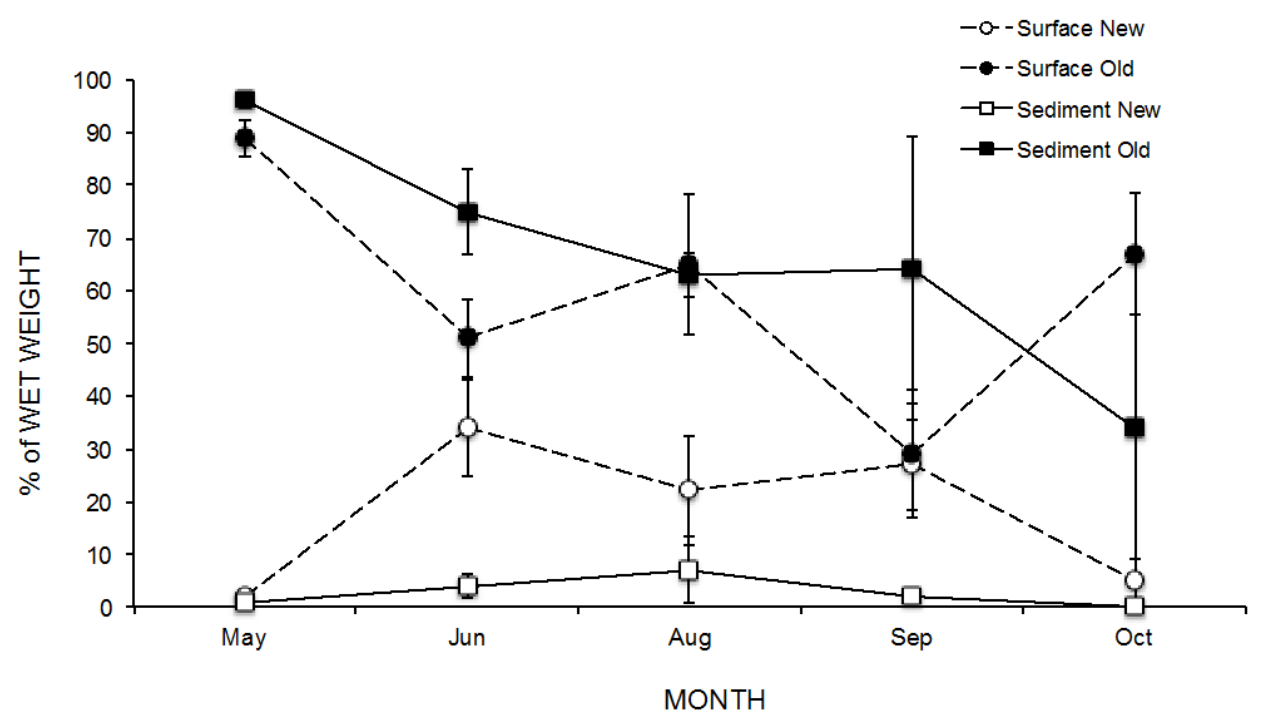

Figure 4 The composition (new versus old) of wrack on beaches of Geographe Bay from 735 May-October 2008.

736 

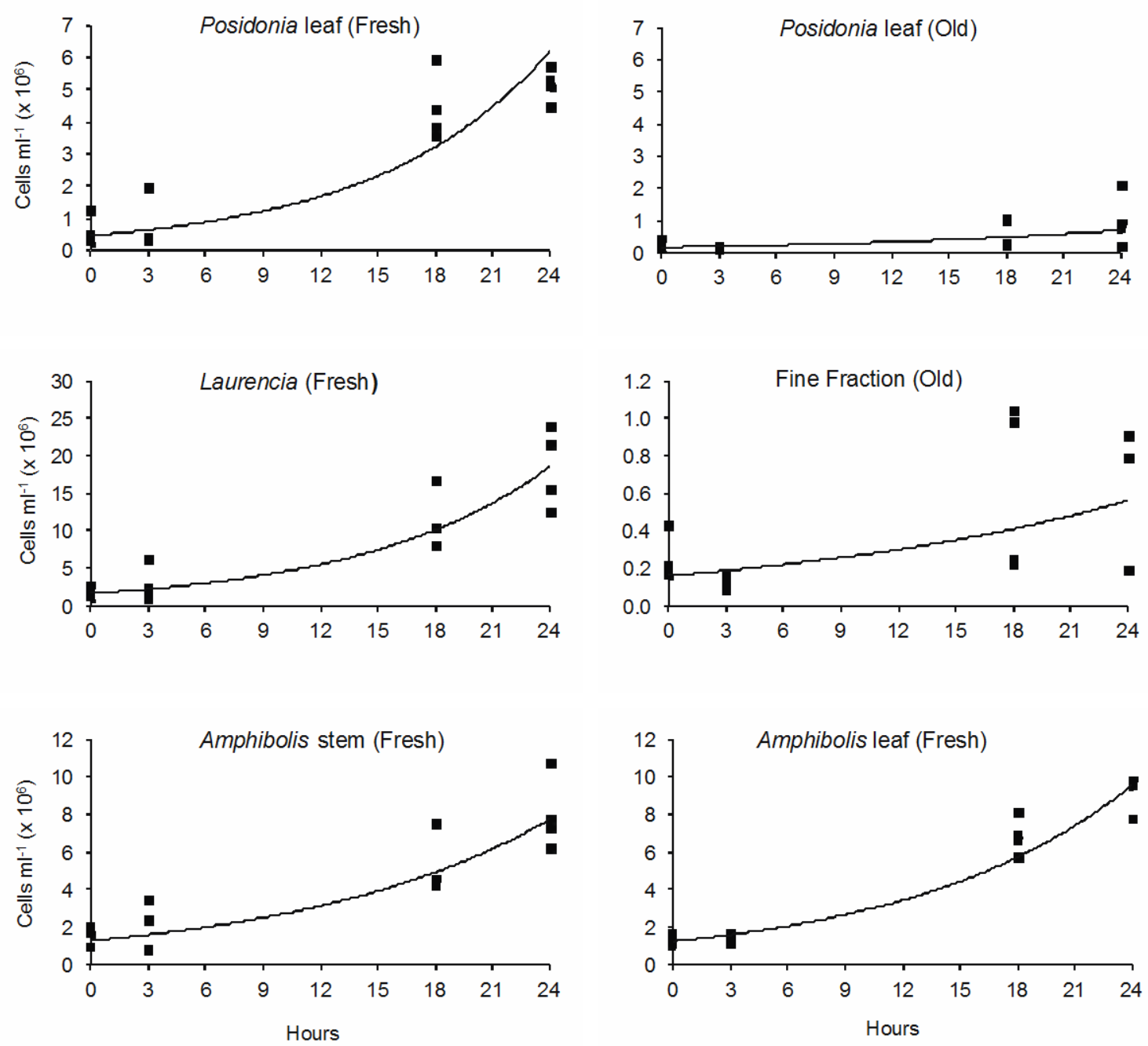

Figure $\mathbf{5}$ Abundance of heterotrophic bacterial cells following addition of an inoculum to DOC leachates from different wrack types. 